\title{
4
}

\section{A Critical Theory Perspective on Faculty Development}

\author{
Stephen D. Brookfield \\ University of St. Thomas
}

This chapter argues that critical theory implies a number of conceptions and practices of teaching, and it applies a critical theory perspective to conducting faculty development. It speculates on how faculty development might be organized according to some insights drawn from critical theory, and it reviews the chief reasons why teachers resist engaging with this perspective.

$\mathrm{M}$

$y$ understanding of critical theory focuses on three core assumptions regarding the way the world is organized: 1) that apparently open, western democracies are actually highly unequal societies in which economic inequity, racism, and class discrimination are empirical realities; 2) that the way this state of affairs is reproduced as seeming to be normal, natural, and inevitable (thereby heading off potential challenges to the system) is through the dissemination of a dominant ideology of capitalism and the natural selection of merit assuring that the most capable and talented rise to the top; and 3) that critical theory attempts to understand this state of affairs as a prelude to changing it. Taken together, these three assumptions explain so much of what I see happening around me, in macro-political terms and also in the intimate spheres of daily life.

When this dominant ideology works effectively, it ensures that an unequal, racist, and sexist society is able to reproduce itself with minimal opposition. It functions to convince people that the world is organized the way it is for the best of all reasons and that society works in the best interests of all. Critical theory regards dominant ideology not as a value-free descriptor of whatever set of beliefs the majority of citizens live by but as inherently manipulative and 
duplicitous. From the perspective of critical theory, a critical adult (and, by implication, a critical teacher) is one who can discern how the ethic of capitalism, and the logic of bureaucratic rationality, pushes people into ways of living that perpetuate economic, racial, and gender oppression. Additionally, and crucially, critical theory views a critical adult as one who takes action to create more democratic, collectivist economic and social forms. Some in the tradition (e.g., Cornel West) link social change to democratic socialism, others (e.g., Erich Fromm) to socialist humanism.

\section{Conceptions and Practices of Teaching Inherent in Critical Theory}

A number of conceptions and practices of teaching seem to me to be inherent in critical theory's formulations. From Marx's 11 th thesis on Feuerbach onwards, I view the theory as full of activist intent. Indeed, as Horkheimer (1972) argues in his essay defining critical theory, the theory can only be considered successful if it produces revolutionary change. Theorizing exists so that people can understand the dynamics of political, economic, racial, and cultural oppression. With that understanding they can then began to challenge these dynamics and learn to create new social forms, particularly new conditions of labor, that allow them to express their creativity. So critical theory is normatively grounded in a vision of a society in which people live collectively in ways that encourage the free exercise of their creativity without foreclosing that of others. In such a society people see their own well-being as integrally bound with that of others. They act toward each other with generosity and compassion and are ever alert to the presence of injustice, inequity, and oppression. Creating such a society can be understood as entailing a series of learning tasks: 1) learning to recognize and challenge ideology that attempts to portray the exploitation of the many by the few as a natural state of affairs, 2) learning to uncover and counter hegemony, 3) learning to unmask power, 4) learning to overcome alienation and thereby accept freedoin, 5) learning to pursue liberation, 6) learning to reclaim reason, and 7) learning to practice democracy.

To teach informed by critical theory is, by implication, to teach with a specific social and political intent. Critical theorists intend that their analyses and concepts will help people create social and cconomic forms distinguished by a greater degree of democratic socialism. Although teaching critically has a transformative impetus, there are noticeable differences in the ways different theorists pursue this. However, one theme-the inevitably directive nature of 
education-remains constant across critical theory. Critical teaching begins with developing people's powers of critical thinking so that they can critique the interlocking systems of oppression embedded in contemporary society. Informed by a critical theory perspective, faculty development would have a very specific and highly political agenda. Its purpose would be to help faculty learn to see that capitalism, bureaucratic rationality, disciplinary power, automaton conformity, one-dimensional thought, and repressive tolerance all combine to exert a powerful ideological sway aimed to ensure that the current system-both within and outside their institutions-stays intact.

Helping faculty to think critically about their practice-an oft-espoused aim of faculty development programs-would take a form very different from what we see at most faculty development days. Critical theory views critical thinking as the educational implementation of ideology critique; that is, as the deliberate attempt to penetrate the ideological obfuscation that ensures that massive social inequality is accepted by the majority as the natural state of affairs. Adults who learn to conduct this kind of critique are exercising true reason; that is, reason applied to asking universal questions about how we should live. Questions considered at faculty development opportunities might be: What kind of college work arrangements and teaching practices will help faculty and students treat each other fairly and compassionately? How can we redesign teaching, staff, and faculty development, promotion and tenure, and the conduct of departmental meetings so that these encourage the expression of human creativity?

This form of critical thinking is only the beginning of critical theory's educational project, however. The point of getting people to think critically is to enable them to create true democracy-what Fromm, Marcuse, West, and others regard as the cornerstone of socialism-at both the micro and the macro level. If adults think critically in this view they will be demanding worker cooperatives, the abolition of private education, the imposition of income caps, universal access to healthcare based on need not wealth, and public ownership of corporations and utilities. Critical thinking framed by critical theory is not just a cognitive process. It is inevitably bound up with realizing and emphasizing common interests, rejecting the privatized, competitive ethic of capitalism, and preventing the emergence of inherited privilege.

Conducting faculty development in a manner informed by critical theory is, therefore, inherently political. It is political because it is intended to help people learn how to replace the exchange economy of capitalism with truly democratic socialism. For faculty within private colleges or proprietary institutions this would be particularly difficult to realize! It is also political 
because it makes no pretense of neutrality, though it embraces self-criticism. Finally, it is political because it is highly directive, practicing, in Baptiste's (2000) terms, a pedagogy of ethical coercion.

\section{Methodological Approaches}

Although critical theorists share a common recognition of the politically directive nature of education, they do not advance any kind of methodological orthodoxy to describe how such education should take place. However, three contrasting methodological clusters or emphases are discernible in the canon, each of which has implications for faculty development. The first of these clusters is the need to teach a structuralized worldview that analyzes private experiences and personal dilemmas as structurally produced. In faculty development terms, a structuralized worldview is one in which teachers are helped to see that individual classroom troubles (e.g., the resistance or sabotage offered by a small group of students, the need to rush through content quicker than one wishes, the imperative of teaching and grading according to a rubric developed by a team of "specialists" one has never met) are actually the result of wider structural forces. Changes in the legislature, a new policy agenda from Washington, DC, the fallout from lurid stories of the failure of higher education that make the tabloids, the prospect of winning a large grant from a local industry-all these factors shape classroom events just as much as the personal histories of the students and teachers involved. (Of course, these personal histories are structural products, too.) Faculty development would help white teachers who work mostly with black and brown students, or black teachers who work mostly with white students, understand how much of the resistance that each teacher faces has been sculpted by years of racial tension and racism.

Two theorists who strongly advocate teaching a structuralized worldview are Erich Fromm (1955) and Angela Davis (1983), though to a degree all in critical theory advocate this. Fromm's perspective as a therapist and social psychologist is that adults' intellectual development means they are much better equipped than children to realize that forces external to their own whims and inclinations shape their lives. He feels that adults' accumulated life experience provides the curricular material that can be analyzed for evidence of the impact of wider social forces. Fromm would clearly see faculty development (comprised as it is of adult participants) as a prime forum for teaching a structuralized worldview. His hope would be that teachers would then become adept at teaching this to their own students. Davis consistently urges 
that any teaching about women's issues must always illustrate how individual lives are shaped, and injured, by the workings of capitalism. For her, this is crucial to the development of political consciousness and to women's psychological well-being. They learn that what they thought were problems visited on them by an arbitrary fate, or the result of personal inadequacy, are in fact the predictable outcome of the workings of capitalism and patriarchy. This is a life-saving realization. For women faculty who consistently suffer from having spent extra time with students rather than closing their door to focus on their own writing, identifying patriarchy in their institutions is particularly crucial. Being denied tenure because one has taken teaching too seriously needs to be worn as a badge of honor, not as shame or self-loathing.

A second pedagogical emphasis in critical theory explores the need for abstract, conceptual reasoning-reasoning that can be applied to considering broad questions such as how to organize society fairly or what it means to treat each other ethically. Critical theorists, particularly Marcuse and Habermas, argue that critical thought is impossible if adults have learned only to focus on particulars, on the immediate features of their lives. For example, people need some basis for comparing the claims of various groups that they should be treated differently because of their history, race, culture, religion, and so on. As long as we live in association with others there has to be restrictions placed on the liberty of those who behave in ways likely to injure others. How we decide what these limits should be is based on some broad concepts of fairness or social well-being. Your right to smoke a cancer-inducing cigarette cannot be exercised regardless in a small room containing asthma, lung cancer, or emphysema sufferers. So if living socially requires the development of rules of conduct that have a level of generality beyond that of individual whims then we need to be comfortable thinking in broad, abstract terms. Deciding which rules should be followed, and how these might be established in ways that ensure their general acceptance, are matters that require a level of thought beyond that of saying, "This is what I want because it works for me in my life." Freedom, fairness, equity, liberation, the ethical use of power-all these "big" ideas are central to the critical tradition and all contain a level of universality entailing the exercise of abstract, conceptual thought.

In a faculty development context, this means asking the "big" questions about the purposes and features of teaching such as: What makes a good teacher? Why do we teach? When do we know that learning is happening? How do we define learning? What does it mean to teach ethically? How and when do we abuse our power as teachers? These are questions we all ponder as teachers, but usually this happens in private. Rarely, if ever, do they surface in a department or faculty meeting or in team-teaching. One of the few times 
I have seen group conversations about these questions among teachers has been in a faculty development context when a group of teachers meets to convert a classroom course to an online format. Under the skilled guidance of an instructional developer's questions, teachers are provided with a rare opportunity to ask basic questions about what they believe is important and why this is so. They are required to clarify among themselves what it is they wish students to be able to accomplish in a course and how learning is recognized. Only once have I seen time for the consideration of such questions included as a matter of course as a regular item on the agenda of a monthly faculty meeting.

A third element stressed in some variants of critical theory is the need for adults to become "uncoupled from the stream of cultural givens" (Habermas, 1990, p. 162). This momentary separation from the demands and patterns of everyday life allows them to view society in a newly critical way. Gramsci and Marcuse argue that a temporary detachment from social life is a necessary spur to critical thought, with Marcuse conducting a sustained analysis of how separation, privacy, and isolation help people to escape one-dimensional thought. This element in critical theory receives less contemporary attention probably because privacy is now, as Marcuse admits, a resource available chiefly to the rich. Also, Marcuse's emphasis on how a powerfully estranging, private engagement with a work of art leads to the development of rebellious subjectivity smacks to some of elitism. It also raises the specter of unrestrained individualism, an element of dominant ideology that prompts deep skepticism among many of a critical cast.

In the practice of faculty development, I believe there is still a place for separation, privacy, and isolation, despite its compromised nature. One of the approaches I use in my own teaching - the emphasis on students doing private, separated, and isolated reading of original critical theory material before engaging in small group discussion of this-is applied in my faculty development work in the context of faculty reflection groups. I am a strong advocate of such reflection groups, particularly those where topics for conversation are under the control of teachers themselves. However, I do not believe that faculty developers can assume that teachers know how to participate in democratic, respectful conversations. The people who talk the loudest and longest inside such groups are often those whose social locations mean their voices get the most attention in the world outside.

I have argued in a book coauthored with Stephen Preskill (2005) that teachers do not leave their racial, class, or gender identities at the meeting room door, nor do they forget their previous participation in meetings and conversations with all the humiliations and manipulations these often en- 
tailed. For a teacher reflection group to look anything remotely like the ideal speech situation described by Habermas, its participants will need to evolve, and adhere to, rules of discourse that exemplify these features. Since the exercise of these rules cannot be left to chance, the group will have to find some way to monitor observance of these.

Because groups are often unwilling to acknowledge and confront the hierarchies and power dynamics they import into their activities, faculty developers can help illuminate these. They can consistently draw attention to the need for inclusive models of conversation such as the circle of voices, circular response, snowballing, or newsprint dialogue (Brookfield \& Preskill, 2005). They can intervene in conversations to stop the most privileged and vociferous from dominating by declaring a ground rule that the next couple of minutes of conversation are reserved for those who up to now have not had a chance to contribute. They can also democratize the conversation by advocating the three-person rule. This rule holds that once someone has made a comment they are not allowed to contribute again until at least three other people have spoken. The only exception to this is if someone else in the group directly asks a speaker to say more about their original comment. Developers can also distribute to the group the results of anonymous participant evaluations if these reveal that some people feel shut down and unheard. And they can acknowledge constantly the fact of their own power and how this is being exercised to create conversational structures that equalize participation and prevent the emergence of an unofficial pecking order of contributions.

\section{Resistance to Faculty Development Conducted in a Critical Theory Key}

In this section I want to reflect on some of my own personal experiences doing faculty development in a way informed by critical theory. This experience has taught me that the one fact on which I can depend in this work is that faculty will resist, often quite strongly, viewing their teaching through the lens of this tradition. Five elements in critical theory seem to present particular problems: 1) the emphasis on Marx, 2) the critique of capitalism the theory entails, 3 ) the questioning of democracy (particularly the identification of the tyranny of the majority), 4) the difficult language used by critical theorists, and 5) the radical pessimism induced by constantly reading analyses that emphasize the power of dominant ideology and the way it effectively forestalls any real challenge to the system. Let me deal with these in turn, beginning with the issue of Marxophobia. 
One of the first things I do when introducing a critical theory perspective is to position it as a response to Marx. I do this as a matter of scholarly honesty. Since I believe Marx's work to be the foundation and fulcrum of critical theory-its theoretical starting point-it would be disingenuous not to make this clear. Hearing this is difficult for some faculty who wonder if it means that only Marxists can make use of critical theory. The rampant Marxophobia commented on by Peter McLaren (1998) means that any body of work connecting to Marx's ideas, no matter how critically these ideas are examined, is immediately suspect. Teachers with a strong commitment to values of individuality, liberation, and creativity-the same values emphasized in Marx's manuscript on alienated labor (Fromm, 1961) - see reading Marx almost as an unpatriotic act. It is as if by opening the pages of Marx's Concept of Man (Fromm, 1961) one is rejecting democracy, free speech, even America itself.

It is important to say that it is not only third or fourth generations who have this difficulty. Teachers from former communist regimes who have fought in wars, suffered the loss of family members, seen the disappearance of livelihoods, and been forced into exile by those regimes also have an understandable visceral reaction to Marx's association with critical theory. It does not seem to matter how many times I point out that critical theorists unequivocally condemn the automaton conformity, surveillance, and onedimensional thought they see in totalitarian communism, or how many times these theorists assert the primacy of true democracy. Once Marx is mentioned-unless it is to denounce anything associated with him-you have immediately created a problem in several teachers' minds.

So how to respond to this situation? One thing is to emphasize early on the self-critical nature of critical theory itself and how this critical perspective is applied to Marx's work as well as to capitalist ideology. I quote Gramsci's warning against the idolatry of Marx, Marcuse's insistence on the need to take a critical approach to critical theory, West's essay on the indispensability yet insufficiency of Marxist theory, and the blindnesses of race and gender in Marx identified by hooks, Davis, Karenga, and others. A useful resource here is Noam Chomsky's (2002) essays on "The Leninist/Capitalist Intelligentsia" and "Marxist 'Theory' and Intellectual Fakery." Chomsky, one of the most prominent leftist scholar-activists in the US, has a long record of public ideology critique, so his credibility is strong. He is scathing about the way Marxism-Leninism reveals, in his view, strong elements of authoritarianism and condescension. These are seen most prominently "in the very idea that a 'vanguard party' can, or has any right to lead the stupid masses towards some future they're too dumb to understand for themselves" (Chomsky, 2002, p. 226). Chomsky views Marx as a theorist of capitalism who has an interesting 
abstract model of how capitalism functions, but one that can be improved on, refined, and broadened. He says he hasn't "the foggiest idea" (Chomsky, 2002, p. 228) what "dialectics" means and admits "when I look at a page of Marxist philosophy or literary theory, I have the feeling that I could stare at it for the rest of my life and I'd never understand it" (Chomsky, 2002, p. 228). For many people, this is enormously reassuring! It is important to stress, however, that Marx should not be introduced so circumspectly as to rob his ideas of any force or power. There is a thin line between encouraging a healthy skepticism of Marx, or of any theorist, and predisposing people to dismiss him. The point is not to set him up for easy demolition, but to demonstrate that a serious reading of Marx can happen without readers feeling they somehow have to convert to Marxism.

The second source of resistance critical theory induces concerns its critique of capitalism, particularly the "single existential judgment" offered by Horkheimer (1972) that critical theory's chief project is studying how to abolish the exchange economy of capitalism. A critique of capitalism-the way it commodifies creativity and labor, makes reason its servant, reduces friendships and intimate relationships to the exchange of personality packages, and fuels spiritual malnourishment-is threaded throughout critical theory. One reason this disturbs people so much is because they recognize features of their own life in this critique. It calls into question the professional location, and by implication the professional practices, of teachers themselves.

We live in a country where capitalism is propounded as dominant ideology, as obviously a "good thing" that supports admired values of freedom, liberty, and individuality. Capitalism is lauded for the prosperity it brings, the technological advances it stimulates, and the way it disseminates the innovative spirit of entrepreneurship among the population. For those working in proprietary institutions, or private colleges that operate as nonprofit institutions, to hear a sustained critique of capitalism, and a documentation of its injuries, is highly threatening. Even faculty in public institutions find themselves increasingly in thrall to capitalist mores as they are exhorted to cut costs, increase their productivity, and become better at attracting customers (students) in an ever more competitive market place.

This is why it is important, early on, to get teachers to distinguish between capitalism's ideology and functioning and their own role in the system. One way to bring teachers to consider a critique of capitalism is through Fromm's analysis of alienation. Fromm is the critical theorist who had the greatest success introducing a Marxist-inclined analysis of American life to mainstream America itself. His outlines of the social character of capitalism with its stress on punctuality, orderliness, and pulling for the team, 
his analysis of the marketing orientation with its emphasis on producing attractive personality packages for exchange on the open market of relationships, and his warnings against the pull of automaton conformity are all couched in still recognizable vignettes and accessible language. As a starting point for understanding Marx, Fromm is far more appealing to suspicious teachers than, say, Gramsci or Althusser. Fromm is also very good at critiquing statist, totalitarian communism, and pointing out the automaton conformity and alienation rampant in totalitarian communist regimes.

A third source of resistance lies in critical theory's condemnation of the way democracy has been distorted to serve capitalism's interests. The radical democratic strain evident in critical theory also regards the realization of genuine democracy as blocked by the simple-minded assumption that a majority vote inevitably ensures the right course of action. Assuming that a majority vote is by definition correct is based on the belief that the choices the majority make represent the free and uncoerced realization of authentically felt needs. Critical theory argues that in reality automaton conformity, onedimensional thought, self-surveillance, and the steering mechanisms of money and power combine to ensure that these supposedly "authentic" majority needs merely mimic dominant ideology. The radical democratic critique holds that in "comfortable, smooth, reasonable, democratic unfreedom" (Marcuse, 1964, p. 1), majority choices are by definition manipulated and compromised, uncritical expressions of needs that capitalism and bureaucratic rationality have created. Contemporary democracy is thus seen as representing the automatic tyranny of the majority, rather than an inclusive, open-ended conversation.

To hear democracy critiqued this way is very tough for a lot of teachers. They can live with a critique of capitalism, but democracy? How can that be bad? Even some who are relatively comfortable with reading critical theory become very alarmed when democracy is called into question. This makes the idea of democracy a fine example of what linguistic philosophy calls a premature ultimate; that is, a term that is held in such reverence that its invocation effectively ends any further debate or critical analysis. Teachers can get away with pedagogical murder if they justify their practice by saying they're striving to act democratically.

One response to the resistance to any critique of the majority vote model of democracy is to remind people that critical theory and democracy are not at odds. There is a radical democratic strand in critical theory that sees genuine participatory democracy as a viable political system, but believes that hegemony has co-opted and distorted this idea to reproduce the current unequal system. This stand is evident particularly in the work of Fromm, Mar- 
cuse (who says that the fact that democracy has never existed does not mean we give up its dream), Habermas, and West. In fact, West positions Marx himself as a radical democrat, arguing that Marx and Engels define communism as a struggle for democracy. This democratic emphasis is evident, in West's view, in the insistence by Marx that "ordinary people, workers, ought to have some control over the conditions of their existence, especially the conditions of their workplace" (West, 1999, p. 223). To West, this is "a profoundly democratic idea" (p. 223) and one, therefore, that can be linked to the mainstream of American ideology. Arguing that Marx is a radical democrat creates some interesting cognitive dissonance for teachers used to thinking of him as the antithesis of all that is democratic.

Finally on this point, one of the things I stress to teachers new to critical theory is the theory's central concern with freedom-a libertarian idea very honored in American ideology. For example, Habermas argues that "socialism and liberty are identical" (Dews, 1992, p. 75), a sentiment many teachers would regard as contradictory. However, Fromm, Marcuse, and Habermas in their different ways all see socialism as "an attempt ... to indicate the necessary conditions which would have to be in place for emancipated life-forms to emerge" (Dews, 1992, p. 145) - to be free in other words. Critical theory is centrally concerned with releasing people from falsely created needs and helping them make their own free choices regarding how they wish to think and live. Framed this way it is much closer to democratic ideals than people realize. Although in many teachers' minds critical theory is essentially a socialistic discourse concerned only with economic arrangements, it can be broadened to privilege freedom as much as common ownership. To North Americans who subscribe to Marxophobia and who are wary of all things socialistic, it is the emphasis in critical theory on claiming freedom that stands the best chance of engaging their interest.

A fourth source of resistance to studying critical theory is its often impenetrable language. Marcuse is one of those who recognizes how the language of critical theory can alienate potential readers and allies. He is particularly perturbed by those who ritualistically invoke terms (proletariat, dialectics, and so on) that are "identification labels for in-groups ... mere clichés" (Marcuse, 1972, p. 39). Mechanically repeating phrases like emancipatory praxis or proletarian hegemony can make those outside the leftist in-group even more convinced that readers of critical theorists live in some kind of fantasy world. Noam Chomsky is another on the left who is most critical of a specialized language of leftism. He declares that "whenever I hear a four-syllable word I get skeptical, because I want to make sure you can't say it in monosyllables" (Chomsky, 2002, p. 229), and he urges people to "be extremely skeptical when 
intellectual life constructs structures which aren't transparent" (Chomsky, 2002, p. 229). In a similar vein, hooks and Davis both argue strongly for an accessible language of critique. Both acknowledge the way everyday language has become distorted by capitalist ideology, and both are quite willing to use many terms drawn from the critical tradition. Both are willing to use autobiographical reflection as a way to ground critique in contexts that connect to readers outside academe. Davis's (1974) own autobiography and hooks's $(1989,2000)$ personal reflections in books such as Talking Back and Where We Stand interweave descriptions of personal episodes with theoretical analyses. Many of these episodes have to do with the excitement of stumbling over a new way of thinking - a theoretical analysis in other words-that explains something in their lives.

Both Davis and hooks believe that much of the revolutionary energy of critical theory has been dampened by its overly convoluted language. How can a teacher galvanize people's desire to question, and then act upon, their world if the language used to do this "mystifies rather than clarifies our condition" (Christian, 1990, p. 572)? This is where Gramsci's idea of the organic intellectual has a particular resonance. To be able to understand a complicated but powerful vocabulary of critique, and to be able to render this in an intelligible and meaningful way to those outside that discourse, is a crucial educational role. Erich Fromm worked to do this as do contemporary commentators such as Ira Shor (1996), Lisa Delpit (1996), Herb Kohl (2000), and Mike Rose (1999). Myles Horton's (1990) use of stories, analogies, and metaphors is one of the best implementations of this that avoided all jargon.

The final point of resistance to critical theory is caused by the radical pessimism it induces. For some people new to the tradition of reading analyses of ideological manipulation, the infinite flexibility of hegemony, the pervasiveness of automaton conformity and alienation, the invasion of the lifeworld, and so on, is like being hit over the head repeatedly with a padded mallet. There seems to be no end to the unrelieved gloom, no prospect of the clouds of oppression ever being blown away. The two worst phases for many people are when they read Foucault on the nature of surveillance and disciplinary power and Marcuse on repressive tolerance. These writings contain the same message of circumspection regarding actions that seem unequivocally hopeful or liberating. Foucault and Marcuse both warn against the easy and seductive assumption that the sincerity of a teacher's intent guarantees that his or her actions will somehow be experienced as liberating. This is sometimes very hard for activist teachers to hear.

Educators drawn to critical theory are often attracted by its oppositional stance. It seems to hold the promise of helping us overcome alienation, un- 
mask power, or learn liberation. When adult teachers encounter an idea like repressive tolerance it seems to sap their energy. On the one hand, their studies in critical theory have created enthusiasm for the possibility of opening up the curriculum to different ideas, thereby galvanizing their own students' activism and developing their critical thinking. Then they read Marcuse's warning that broadening the curriculum often serves only to emphasize the dominance of the existing center and they feel robbed of hope. "How can we do anything," they ask, "when Marcuse says that opening things up really only closes them down further, and Foucault tells us our efforts to democratize education will be experienced as oppressive by those we're seeking to help?"

There is not a lot one can say in response to such a question. But just shrugging your shoulders is not an option either. I usually reply by talking about the importance of using whatever energy you have most effectively. More particularly, I focus on the importance of not wasting energy obsessing fretfully over things you can't control. It seems to me that teachers trying to get students to think and act critically need to be aware of the many traps that lie in wait for them. One of these is working diligently to promote practices that you feel are unequivocally positive without realizing their potentially negative consequences. To act believing you are changing the world for the better, and then to find out that the converse is the case, is horribly demoralizing. It kills the transformative impulse and induces a profoundly debilitating pessimism.

As a teacher I would rather know of the traps and dangers that lie ahead, no matter how much they might complicate matters. If I am aware of the contradictions and complications of teaching critically, then when these present themselves I am less likely to feel that I have single-handedly caused them to appear. In her book Practice Makes Practice, Britzman (1991) identifies the belief that "everything depends on the teacher" as one of the most enduring myths teachers learn early on in their careers. This myth holds that successes are due to your brilliance and failures to your incompetence. We need to dispel this myth with its Copernican emphasis on the teacher as the center of the universe. Given that teaching critically is a pothole-strewn highway we need to know that the reason the car is banging about in such a perilous and unpredictable manner is because of the holes already in the blacktop, not because we are unable to drive.

I realize that much of this chapter may seem far removed from the day-today realities of much faculty development work. For many of us, just getting teachers to show up at faculty development events is a triumph in itself. The last thing we want to do is risk scaring them away with a focus on seemingly needlessly political, overly confrontational themes. It seems to me, however, 
that faculty development-like teaching itself--tries to start where people are, and then to nudge them toward a different, and more critical, understanding of everyday reality. In this regard the focus of this volume on the sociological imagination is entirely appropriate. The private troubles of teachers that they bring to faculty development efforts with the hope of receiving assistanceparticularly that of receiving poor evaluations from students that threaten their continued employment, merit pay, or effort to achieve tenure-provide a perfect entry to a critical theory analysis. I would argue that you cannot accurately understand the way students' ratings of instruction affect your career without appreciating the way that the dominant ideology of capitalism and bureaucratic rationality commodifies learning and teaching. According to this ideology, the value of learning can be assessed by the grade it receives. Such a grade is deemed to represent accurately the internal value of learning. In this way learning is fetishized; that is, deemed to have a standardized, internal worth that can be assigned an unequivocal value. Learning becomes equated with the production of an artifact-an essay, test, or lab-to which this value can be assigned. Similarly, teaching is also commodified-judged to be an object containing unequivocal, standardized worth that is measured by the average of student ratings. So, far from critical theory being an abstracted body of ideas of interest only to those with leftist or philosophical leanings, it is a heuristic of enduring relevance.

\section{References}

Baptiste, I. (2000, May). Beyond reason and personal integrity: Toward a pedagogy of coercive restraint. Canadian Journal for the Study of Adult Education, 14(1), $27-50$.

Britzman, D. P. (1991). Practice makes practice: A critical study of learning to teach. Albany, NY: State University of New York Press.

Brookfield, S. D., \& Preskill, S. (2005). Discussion as a way of teaching: Tools and techniques for democratic classrooms (2nd ed.). San Francisco, CA: Jossey-Bass.

Chomsky, N. (2002). Understanding power: The indispensable Chomsky (P. R. Mitchell \& J. Schoeffel, Eds.). New York, NY: The New Press.

Christian, B. (1990). The race for theory: Science, technology and socialist feminism in the 1990s. In K. V. Hansen \& I. J. Philipson (Eds.), Women, class, and the feminist imagination: A socialist-feminist reader (pp. 568-579). Philadelphia, PA: Temple University Press. 
Davis, A. Y. (1974). Angela Davis: An autobiography. New York, NY: International Publishers.

Davis, A.Y. (1983). Women, race, and class. New York, NY: Vintage Books.

Delpit, L. D. (1996). Other people's children: Cultural conflict in the classroom. New York, NY: New Press.

Dews, P. (Ed.). (1992). Autonomy and solidarity: Interviews with Jurgen Habermas (Rev. ed.). New York, NY: Routledge.

Fromm, E. (1955). The sane socicty. New York, NY: Holt, Rinehart, \& Winston.

Fromm, E. (1961). Marx's concept of man. New York, NY: Frederick Ungar.

Habermas, J. (1990). Moral consciousness and communicative action (C. Lenhardt \& S. W. Nicholsen, Trans.). Cambridge, MA: MIT Press.

hooks, b. (1989). Talking back: Thinking feminist, thinking black. Boston, MA: South End Press.

hooks, b. (2000). Where we stand: Class matters. New York, NY: Routledge.

Horkheimer, M. (1972). Critical theory: Selected essays. New York, NY: Herder and Herder.

Horton, M. (1990). The long haul: An autobiography. New York, NY: Doubleday.

Kohl, H. (2000). The discipline of hope: Learning from a lifetime of teaching. New York, NY: New Press.

Marcuse, H. (1964). One-dimensional man: Studies in the idcology of advanced industrial society. Boston, MA: Beacon Press.

Marcuse, H. (1972). Counterrevolution and revolt. Boston, MA: Beacon Press.

McLaren, P. (1998). Life in schools: An introduction to critical pedagogy in the foundations of cducation (3rd ed.). New York, NY: Longman.

Rose, M. (1999). Possible lives: The promise of public education in America. New York, NY: Penguin.

Shor, I. (1996). When students have power: Negotiating authority in a critical pedagogy. Chicago, IL: University of Chicago Press.

West, C. (1999). Cornel West on heterosexism and transformation: An interview. In J. A. Segarra \& R. Dobles (Eds.), Learning as a political act: Struggles for learning and learning from struggles (pp. 290-305). Cambridge, MA: Harvard University Press. 